\title{
Semen bacterial contamination: Antibiotics susceptibility pattern and standard sperm parameters in men of Birjand, 2017
}

\author{
Mohamad Reza Doostabadi $^{1}\left(\mathbb{D}\right.$, Diba Abazari $^{2}$ (D), Masoud Yousefi ${ }^{3}$ (D), \\ Ali Hosseininejad-Mohebati ${ }^{4}$ D ${ }^{\text {Sedigheh Solymani }}{ }^{5}$ (D), Mohsen Foadoddini ${ }^{6}$
}

${ }^{1}$ Yazd Reproductive Sciences Institute, Yazd University of Medical Science, Yazd, Iran.

${ }^{2}$ Medical Doctor (M.D), Birjand University of Medical Sciences, Birjand, Iran.

${ }^{3}$ Infectious Diseases Research Center, Birjand University of Medical Sciences, Birjand, Iran.

${ }^{4}$ Legal Medicine Research Center, Legal Medicine Organization, Tehran, Iran.

${ }_{6}^{5}$ Department of Biology, Damghan Branch, Islamic Azad University, Damghan, Iran.

${ }^{6}$ Corresponding author; Cardiovascular Diseases Research Center, Birjand University of Medical Sciences, Birjand, Iran. Tel: +9832381206 Fax: +9832381206 E-mail: Foadmohsen@yahoo.com

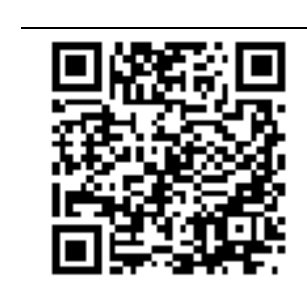

Citation Doostabadi MR, Abazari D, Yousefi M, Hosseininejad-Mohebati A, Solymani S, Foadoddini M. [Semen Bacterial contamination: Antibiotics susceptibility pattern and standard sperm parameters in men of Birjand,2017]. J Birjand Univ Med Sci. 2020; 72(2): 172-81. [Persian]

DOI http://doi.org/10.32592/JBirjandUnivMedSci.2020.27.2.105

Received: September 30, 2019

Accepted: January 6, 2020

\begin{abstract}
Background and Aim: Urinary tract infections can be one of the most important causes of infertility in men. Identification of semen bacterial contamination and using of appropriate antibiotic treatment can cause to improvement sperm parameters. The aim of this study was to evaluate the frequency of bacterial contamination of semen and its effect on standard sperm parameters.

Materials and Methods: In this descriptive-analytical study, the semen analysis of 40 men referring to Birjand laboratories was performed by using the CASA model spermogram device. The Eosin-Nigrosin staining was used to evaluate of sperm viability. After semen samples were cultured on microbial culture media, bacterial contamination was assessed by using conventional microbiological methods. The determination of antibiotic susceptibility of bacterial isolates was performed by the disk diffusion method.

Results: In the present study, $30 \%$ of semen 12 samples were detected with bacterial contamination, the most frequent of which was related to Escherichia coli $(41.7 \%)$. Statistical analysis showed that there was a significant relationship between bacterial contamination of semen and history of urinary tract infection (UTI) $(\mathrm{P}=0.001)$. There was a significant decrease in the motility, viability and sperm count in subjects with bacterial semen contamination $(\mathrm{P}<0.05)$. Nitrofurantoin, Gentamicin and third-generation of Cephalosporins were reported as the most effective treatment options for reducing bacterial contamination in semen.
\end{abstract}

Conclusion: The bacterial contamination of semen can significantly reduce the motility, viability and sperm count. Due to the high prevalence of bacterial contamination in semen and its significant association with sperm factors, the microbial screening of infertile couples without clinical symptoms is essential.

Key Words: Antibiotic Resistance; Bacterial Contamination; Infertility; Semen Fluid; Sperm 


\title{
آلودكى باكتريايى مايع سمن: التكوى حساسيت آنتىبيوتيكى

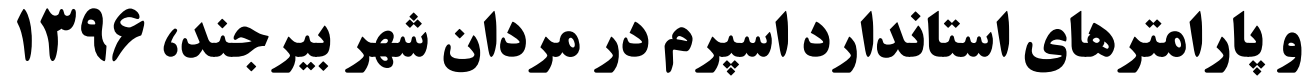

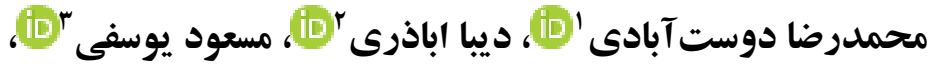

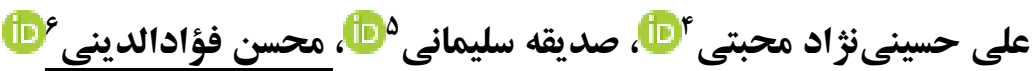

\section{جكيله}

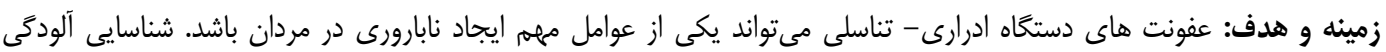

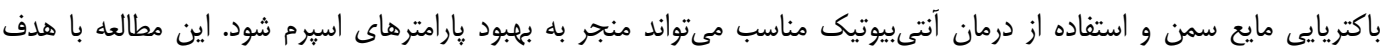

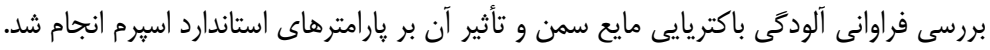

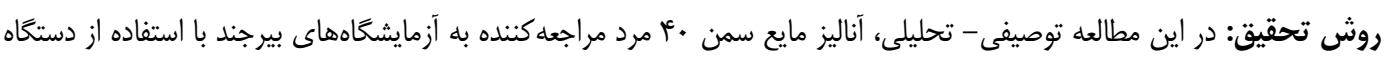

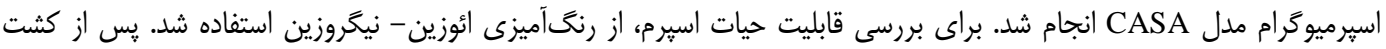

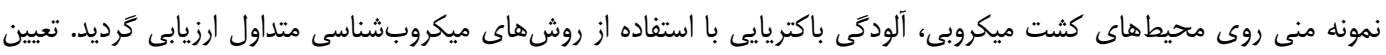

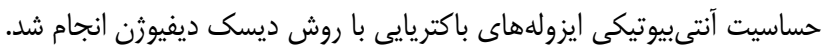

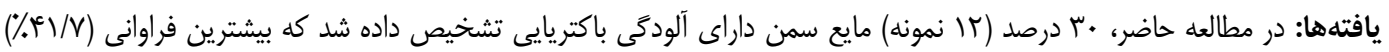

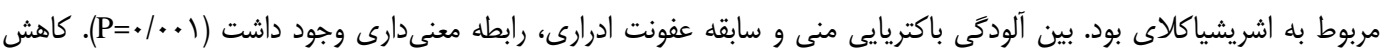

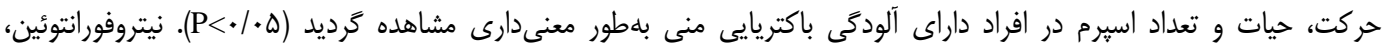

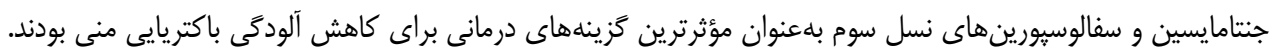

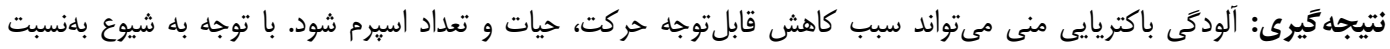

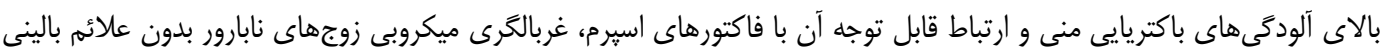

$$
\text { ضرورى به نظر مىرسل. }
$$

$$
\begin{aligned}
& \text { وازههاى كليدى: مقاومت آنتى ييوتيكى؛ آلودىى باكترياي؛ نابارورى؛ مايع سمن؛ اسيرم }
\end{aligned}
$$

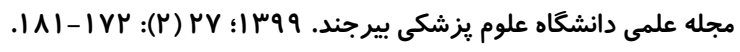

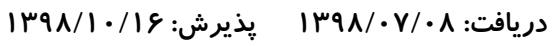

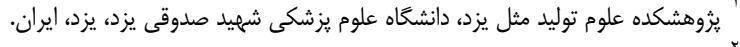

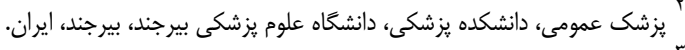

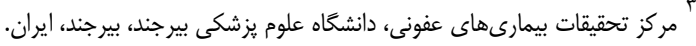

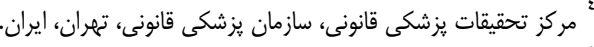

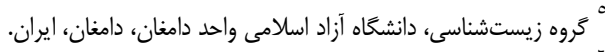

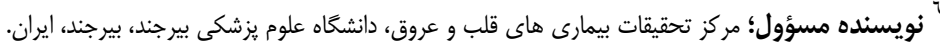

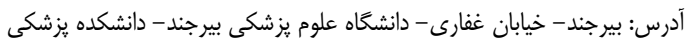


است كه اجتناب از آلودىى مايع سمن تقريباً غيرممكن است، مقله

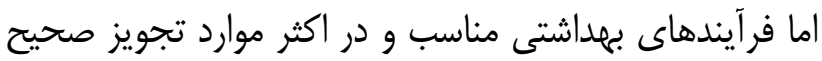
آنتى بيوتيك مى تواند آلودگى باكتريايى مايع سمن را رابه به ميزان

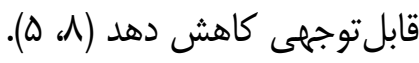
با توجه به اهميت آلودَّى باكتريايى مايع سمن در مردان إنان

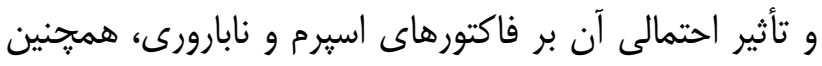

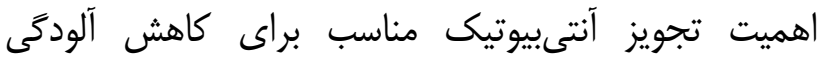

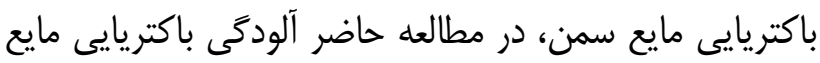

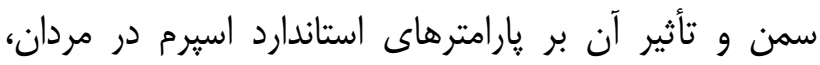

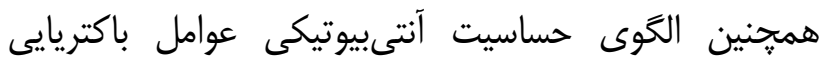
آلوده كننده مايع سمن، مورد بررسى قرار كرفت.

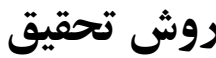

\section{جمعيت بيمار و جمع آورى نمونه مايع سمن:}

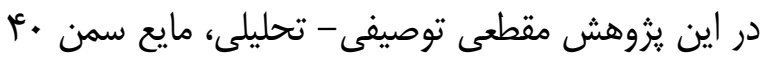

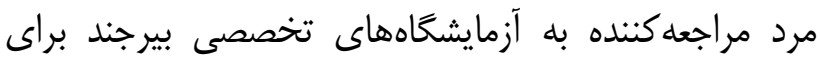

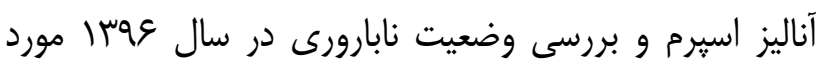

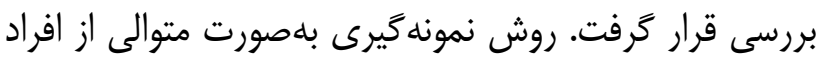

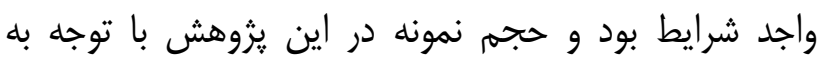

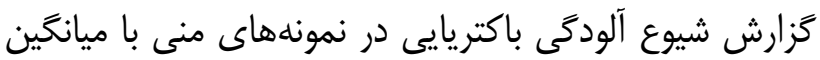

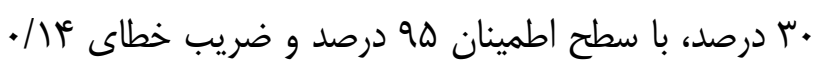

$$
\text { تعيين كرديد. }
$$

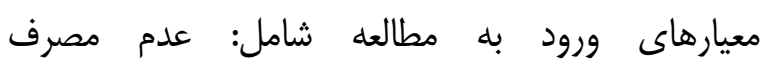

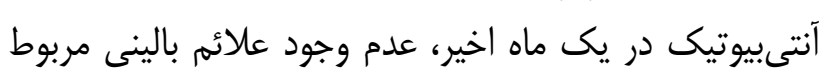

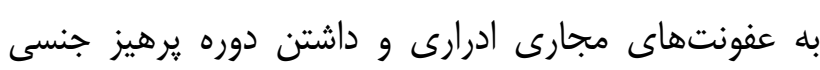
حداقل بdمدت هץ ساعت بود. (Abstinence Duration) يس إز كسب تأييديه كميته اخلاق دانشكاه علوم يزشكى

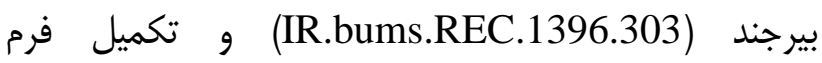
رضايتنامه آكاهاهانه، اطلاعات دموكرافيك و همجنين سابقه عفونتهاى ادرارى افراد مورد مطالعه ثبت شد.

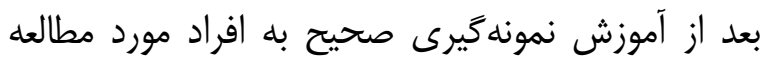

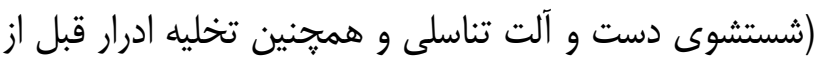

نابارورى يكى از مشكلات رو به رشد بهداشتى در اكثر

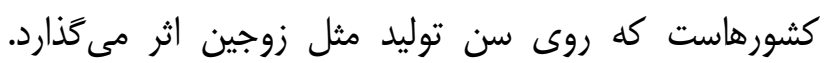

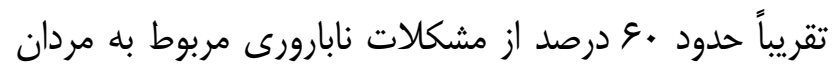

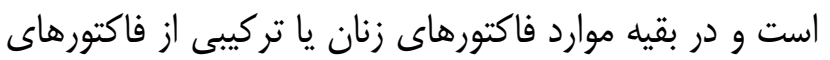

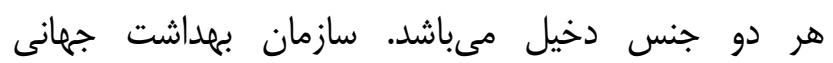

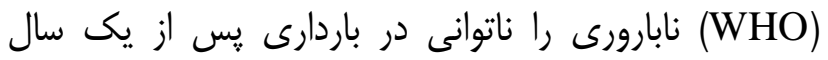
مقاربت منظم و بدون محافظت تعريف مى كند (آ، ()).

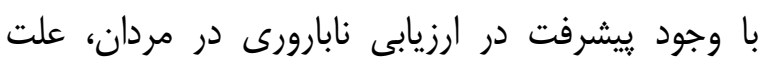

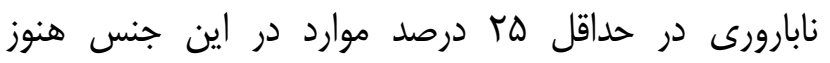

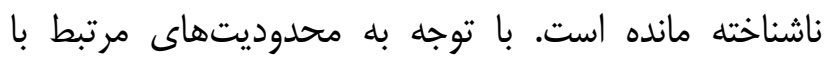

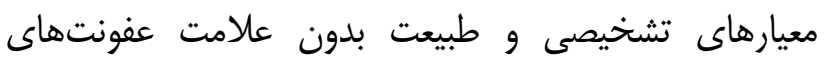

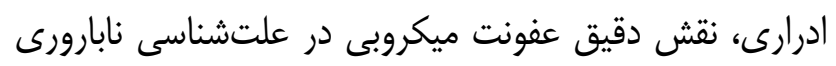
بلهور شفاف مشخص نيست؛ با اين حال، جداسازى ميكرواركانيسمها از مايع سمن مردان بلهويثه مردان نابارور نيان

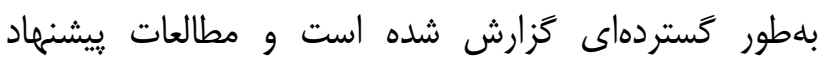

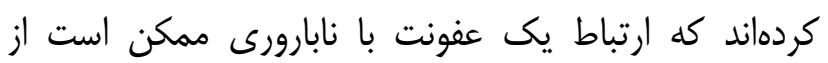

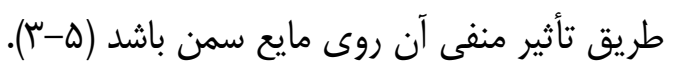

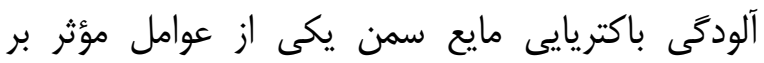

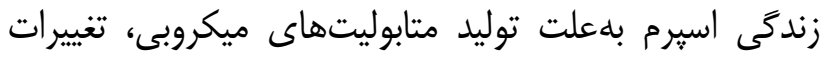

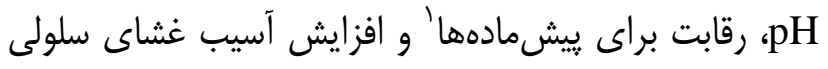

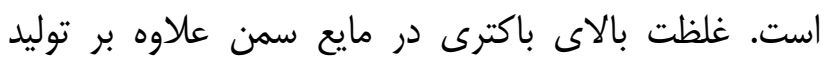
بلهنسبت بالايى از سلولهاى اسيرم غيرطبيعى، موجب كاهش

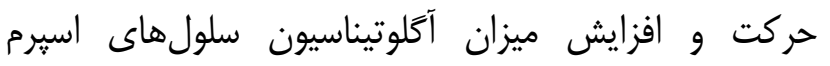

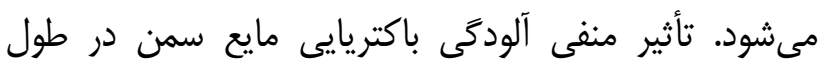

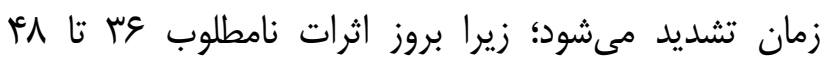

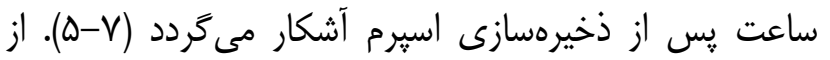

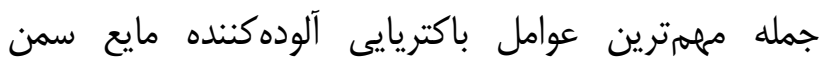

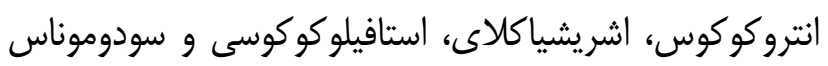
هستند كه اين عوامل مىتوانند با ايجاد التهاب إيبديديم و و يروستات سبب اختلال در يارامترهاى اسيرم كردند. قابل ذكر إنائ 
(MAST Co., UK) ينىسيلين، جنتامايسين، سفتىزوكسيه، سفورتاكسيه،

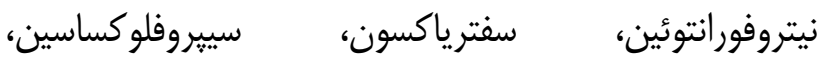
تتراسايكلين، ونكومايسين، كلوكساسيلين، كلرامنين، اريترومايسين و ترىمتويريم- سولفامتوكسازول بود.

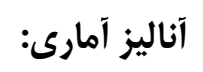

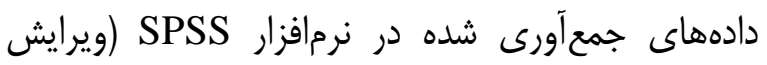

آr) و با استفاده از آزمونهاى آمارى Student T-test Fisher's exact test Chi-square

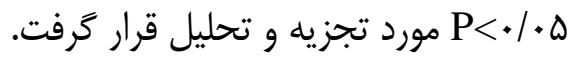

يافته ها

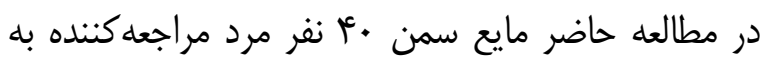

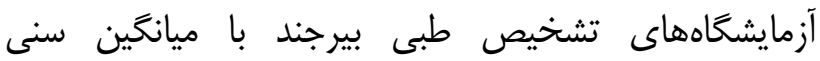

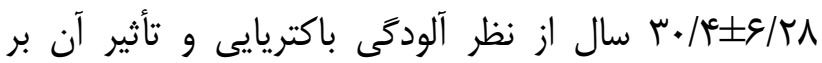

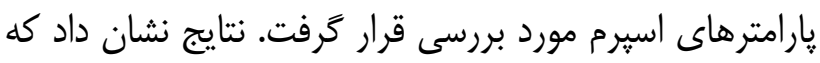

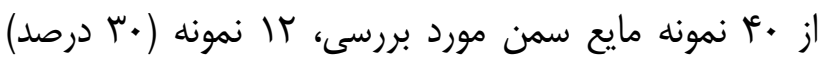

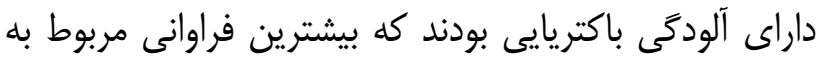

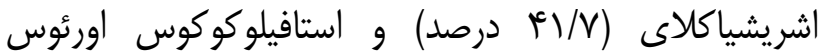

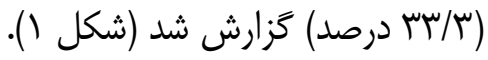

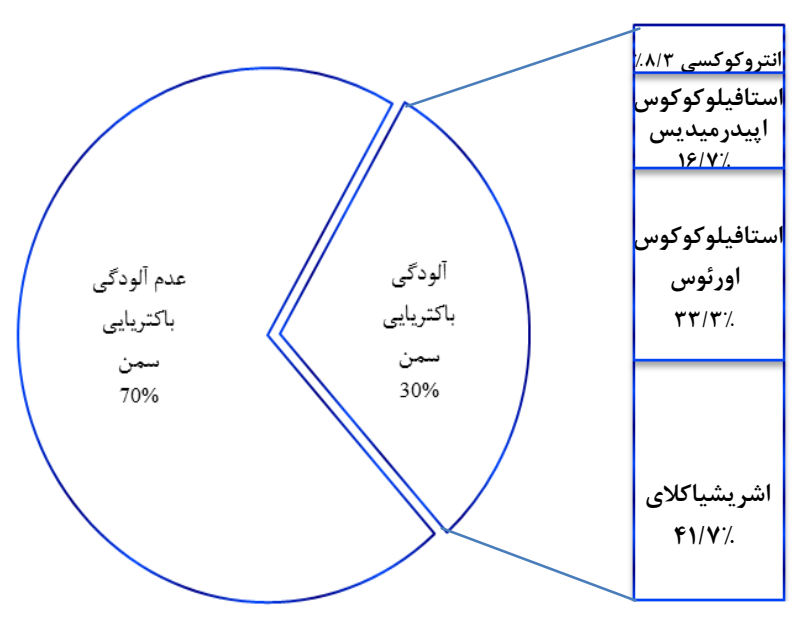

شكل إ- فراوانى نسبى تَونههاى باكتريايى آلودهكنده مايع سمن

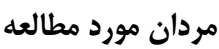

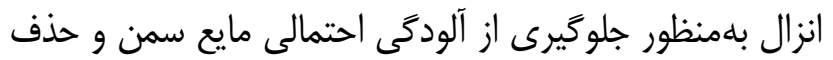

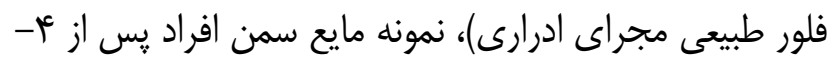

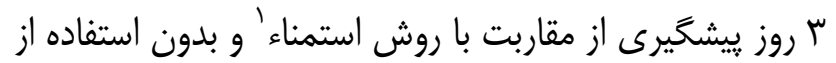

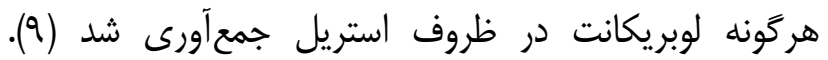
نمونهها بهسرعت در دماى ه درجه سانتى كراد اد به آزمايشكاه منتقل كرديد.

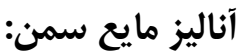

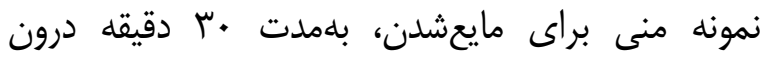

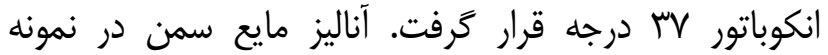
اوليه، طبق دستورالعمل سازمان بهداشت جهانى سال •.1.

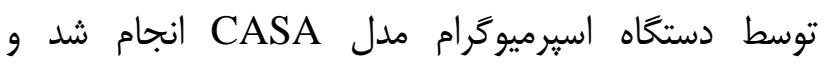
يارامترهاى تعداد، مورفولوزى و تحرى اسيرم توسط دستخاه

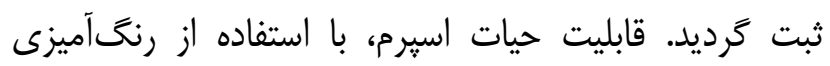

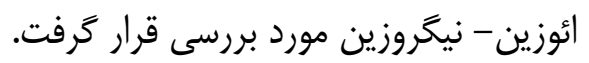

\section{آلودتى باكتريايى مايع سمن:}

در مطالعه حاضر بلمنظور شناسايى باكترى هوازى و 1. بىهوازى اختيارى غير سخت رشد در مايع سمن، ميزان ميكروليتر از نمونه منى با سر سمبلر استريل به به محيطهاى

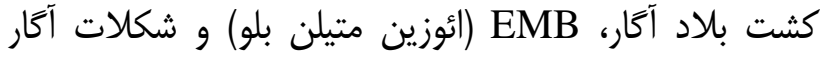

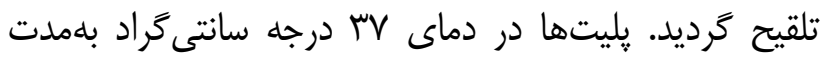

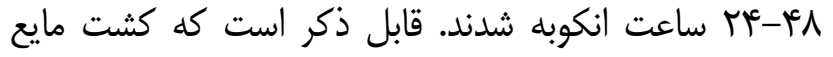
سمن در موارد با تعداد كلنى باكتريايى

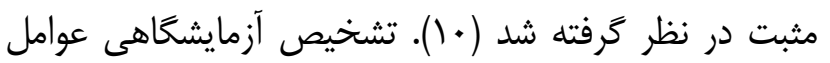

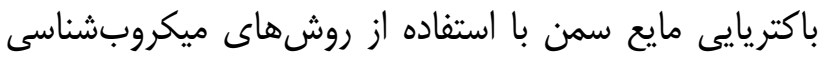

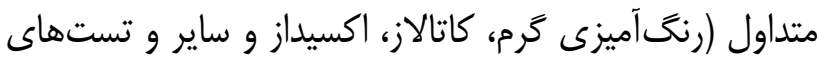
بيوشيميايى) انجام كرفت.

\section{حساسيت آنتى بيوتيكى:}

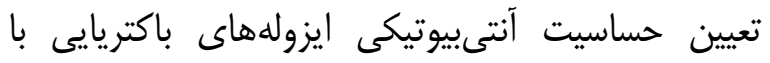
استفاده از روش ديسك ديفيوزن و براساس رهنئ إنمودهاى CLSI

\footnotetext{
1 Masturbation

${ }^{2}$ Clinical and Laboratory Standards Institute
} 


$$
.(\mathrm{P}=\bullet / \cdots+)
$$

آلودكى باكتريايى منى و فاكتور هاى دموكر افيك:

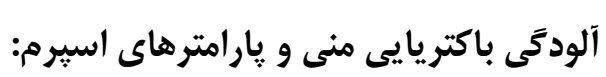

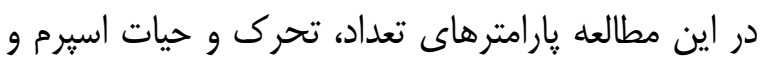

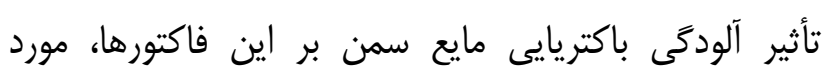

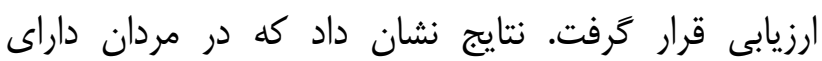

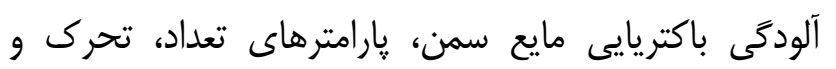

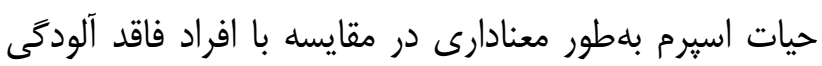

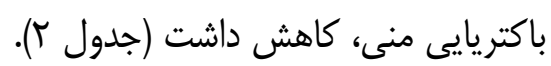

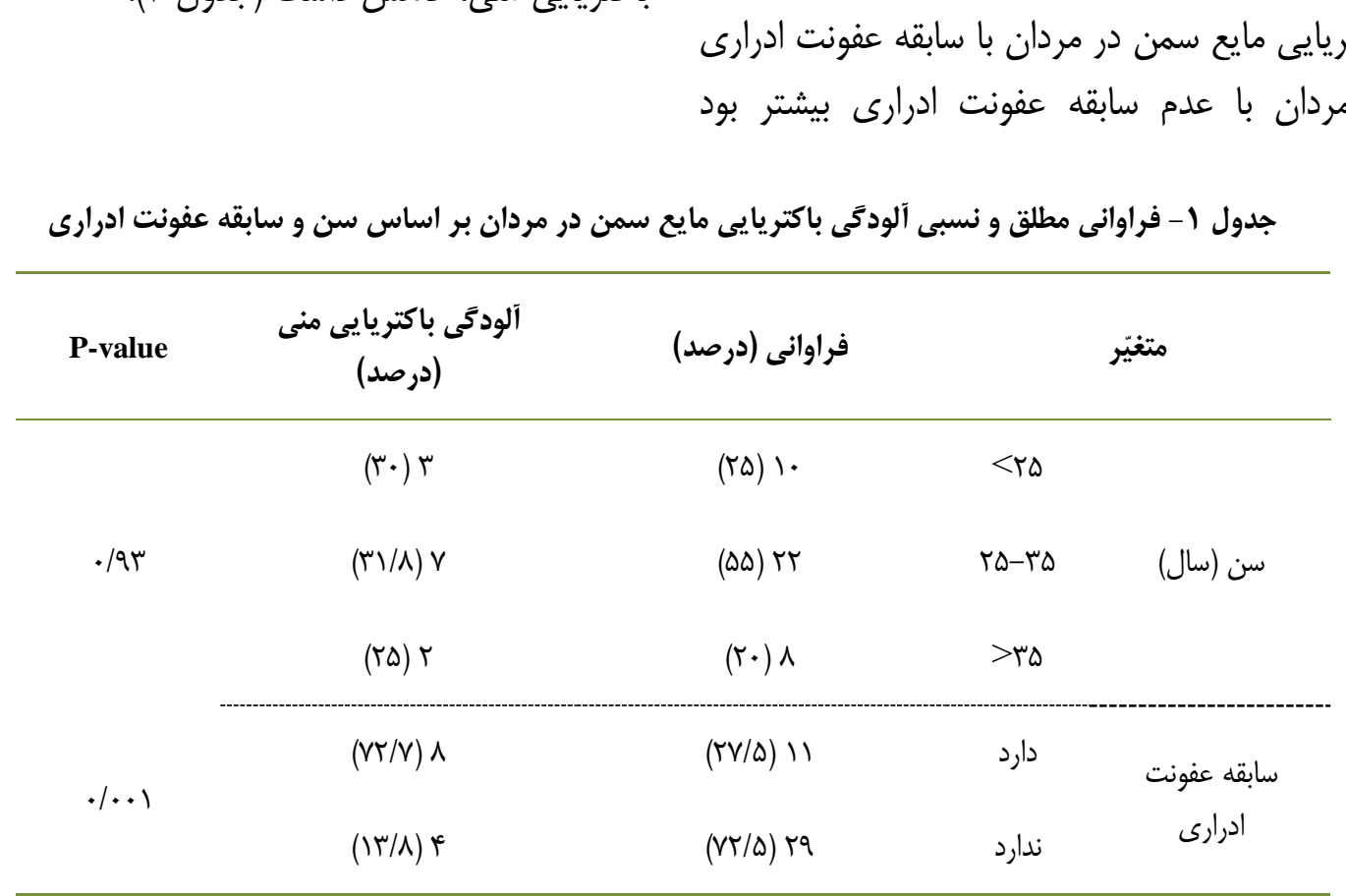

جدول ץ- مقايسه ميانكَين پارامترهاى اسبرم در دو تروه از مردان داراى يا فاقد آلودَى باكتريايى مايع سمن.

\begin{tabular}{|c|c|c|c|}
\hline P-value & 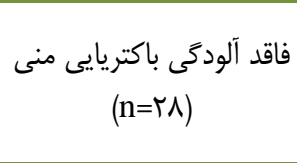 & داراى آلودگى باكتريايى & يارامتر اسيرم \\
\hline.$/ . .1$ & $V F / a r \pm 1 . / .$. & $\Delta r / q q \pm|r / v|$ & حركت (درصد) \\
\hline.$/ . .1$ & $V c / a r \pm r / V \Lambda$ & $\varepsilon N / q) \pm r / q V$ & حيات (درصد) \\
\hline$\cdot 1 \cdot{ }^{c}$ & $W / V Q \pm r N \cdot r$ & $\Delta F / \Delta F \pm r N / M \Lambda$ & تعداد (10\% × × \\
\hline
\end{tabular}


دوره rV، شماره r، تابستان 9 9

مجله علمى دانشگاه علوم يزشكى بيرجند

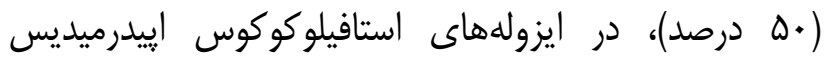

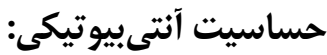

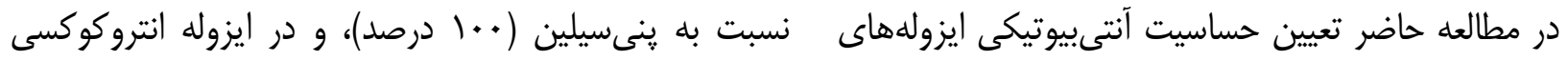

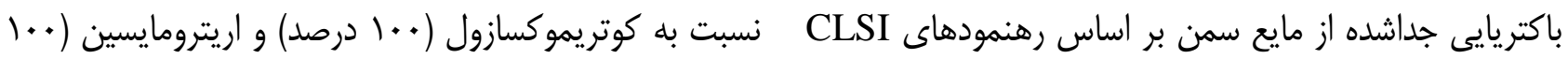

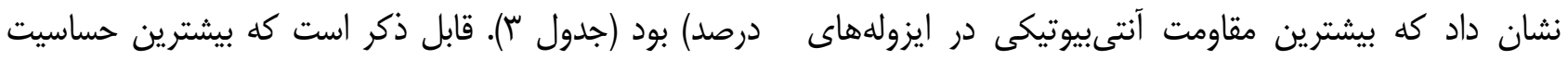

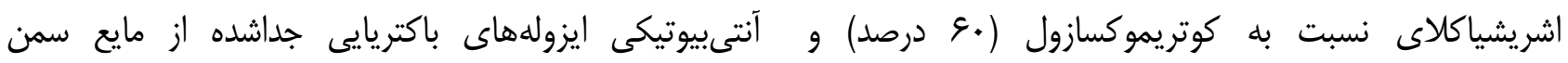

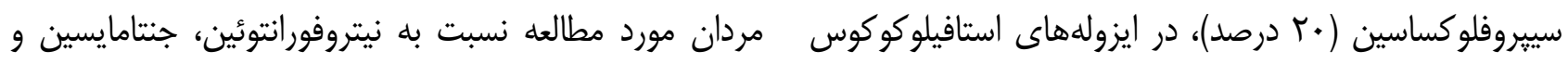

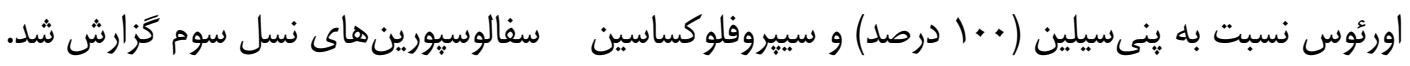

جدول بـ الحَوى مقاومت أنتىبيوتيكى ايزولههاى باكتريايى جداشده از مايع سمن

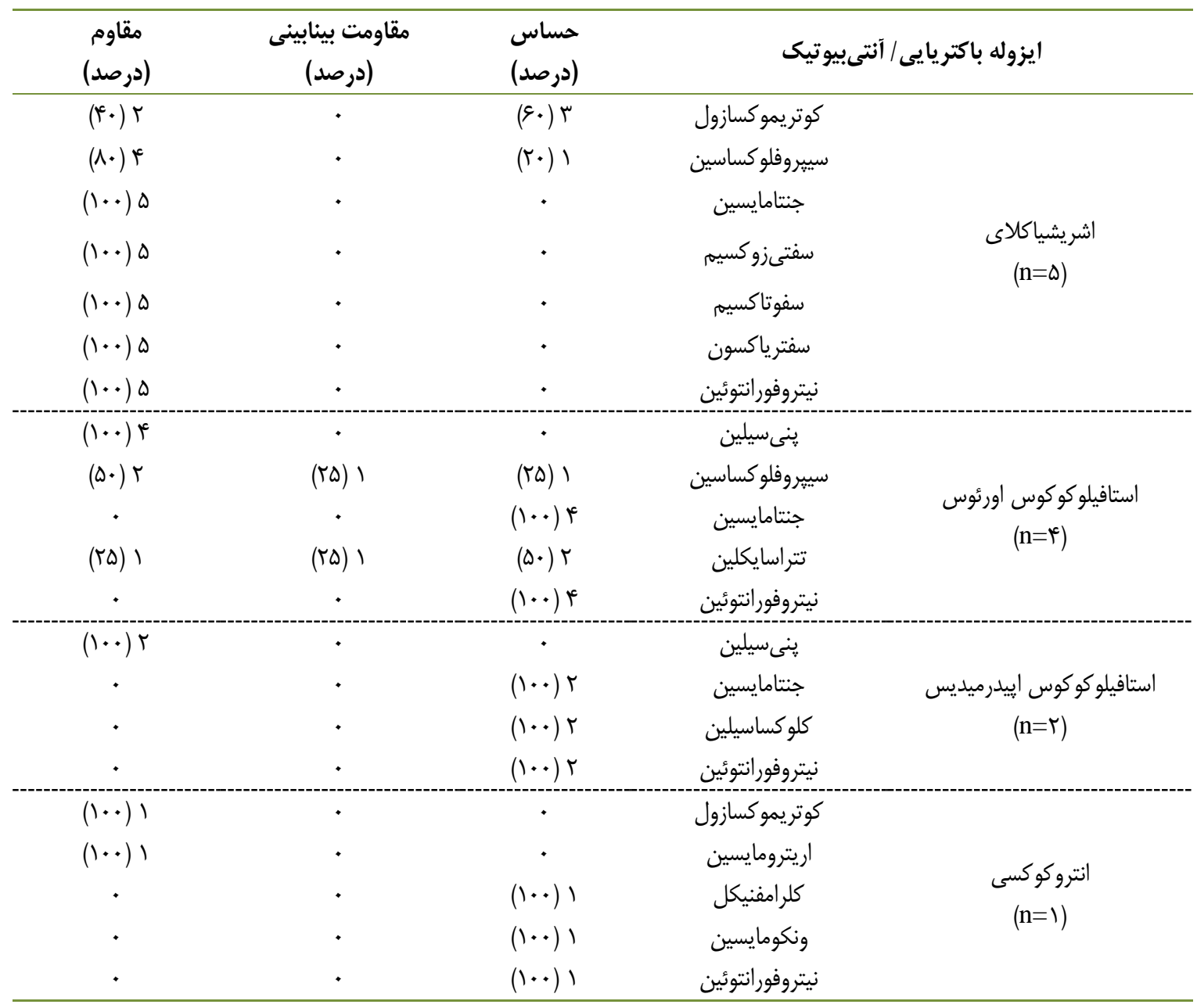

IV 
اورئوس (ץ/ بـ درصد) بود. در مطالعه نبى و همكاران (ايران)،

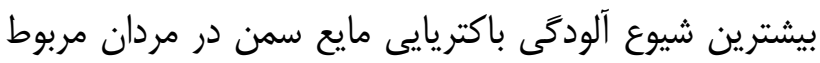

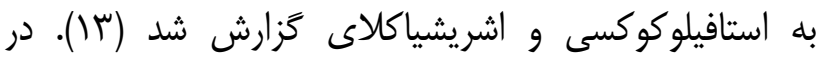
مطالع Merino و همكاران (مكزيك)، بيشترين فراوانى

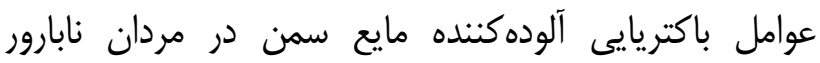
بلهترتيب: مربوط به استافيلوكوكوس إيبدرميديس (باكو درصد)،

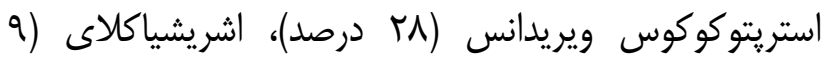

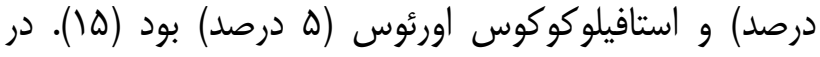

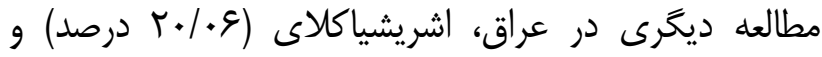

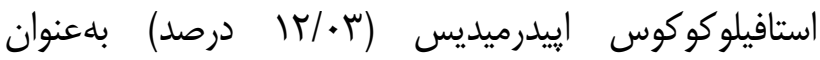

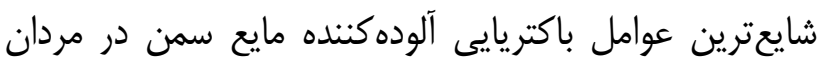
معرفى شدند (ع). نتايج مطالعه حاضر با بسيارى از مطالعات

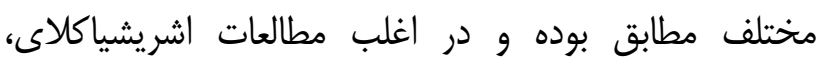

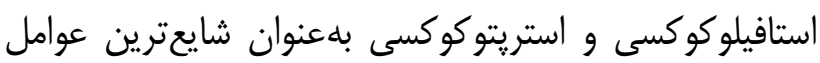
باكتريايى آلودهكنده مايع سمن مردان كزارش شدان

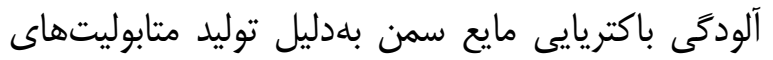

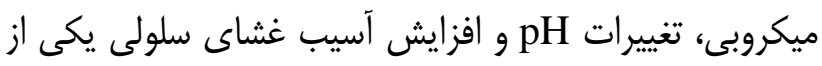

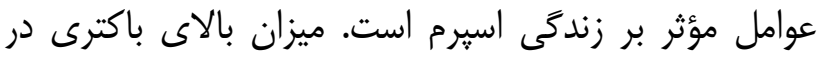
مايع سمن علاوه بر توليد بهنسبت بالايى از سلولهيت الهاى اسيرم

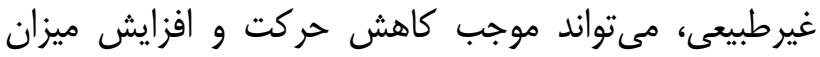

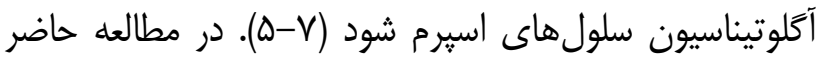

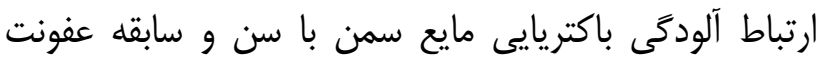

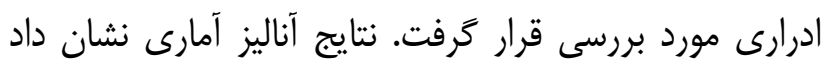

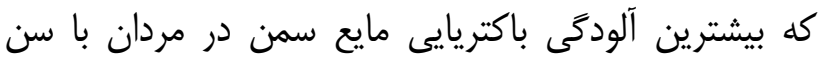

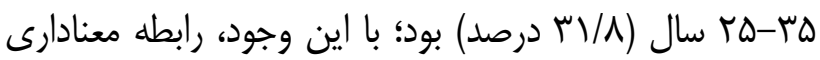

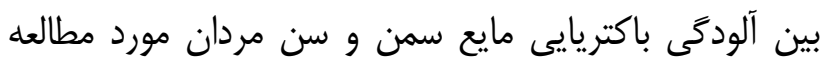

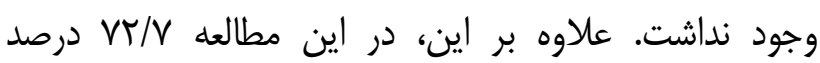

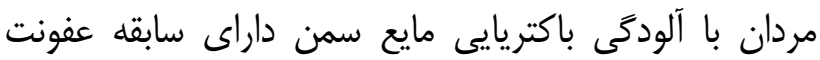

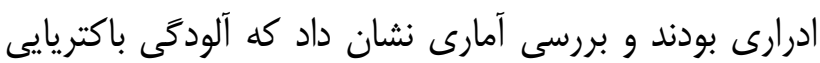
مايع سمن در مردان با سابقه عفونت ادرارى نسبت به به مردان

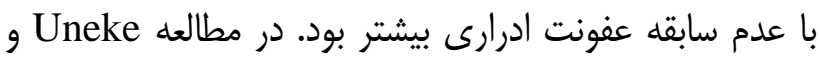

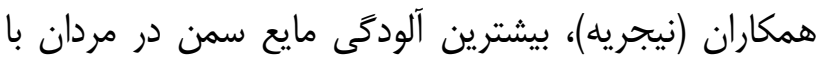

نابارورى يكى از مشكلات رو به رشد بهداشتى در اكثر بئر كشورهاست و با وجود بيشرفت در ارزيابى نابارورى در مردان،

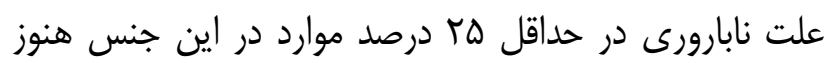

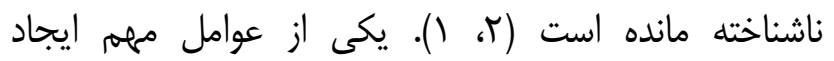

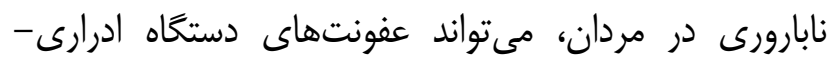

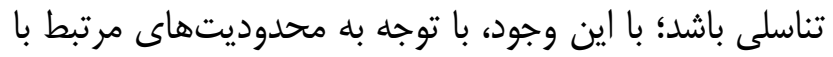

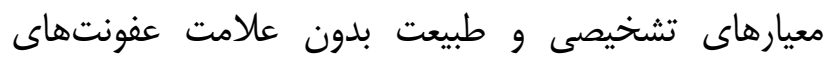

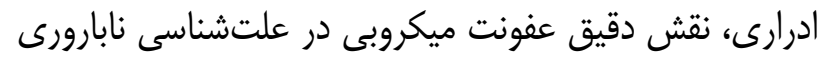

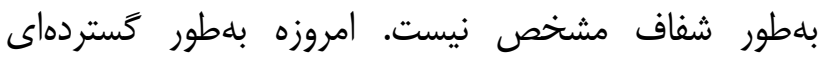
جداسازى ميكروار كانيسمها از مايع سمن مردان بلهويزه مردان

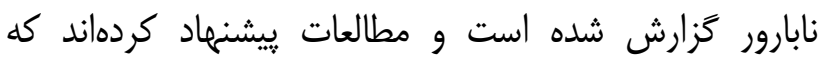

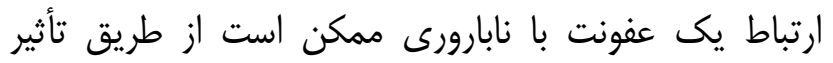
منفى آن روى مايع سمن باشد (ه- بَ).

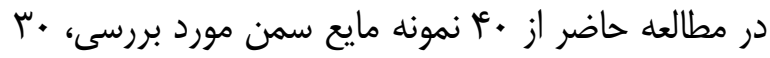
درصد (rا نمونه) داراى آلودگى باكتريايى بودند. در مطالعه Alavi

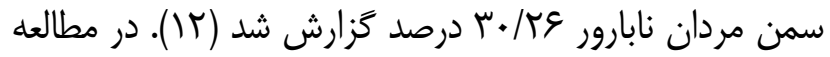
ديخرى در ايران، ميزان آلودىى مجراى ادران ادرارى و مايع سمن

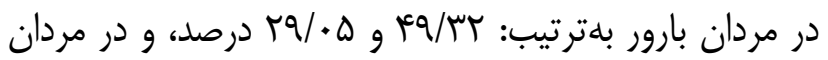

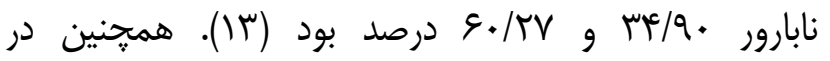

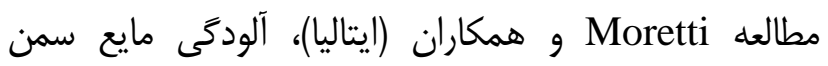

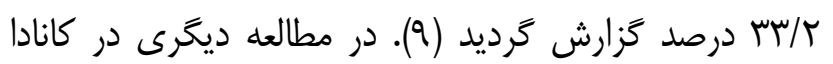

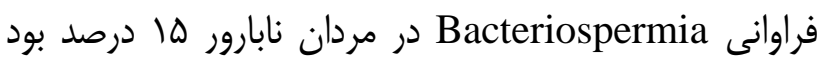

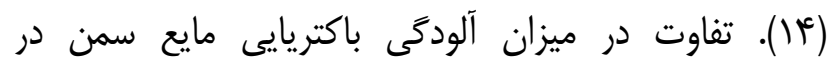

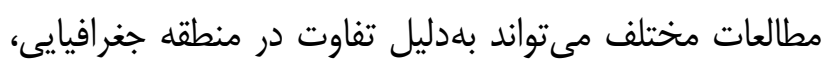

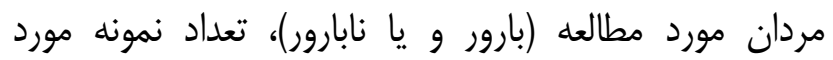
بررسى، روش تشخيصى و يا فاكتورهاى دخيل از قبيل سابقه عفونت ادرارى باشد. در اين مطالعه از بين كشتهاى مثبت از نظر آلودگى باكتريايى مايع سمن مردان مورد بررسى، بيشترين فراوانى إنى

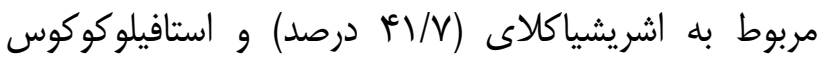


اشريشياكلاى نسبت به كوتريموكسازول و سييروفلوكساسين،

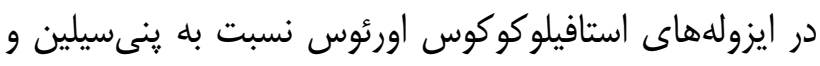
سييروفلوكساسين، در ايزولههاى استافيلوكوكوس اييدرميديس

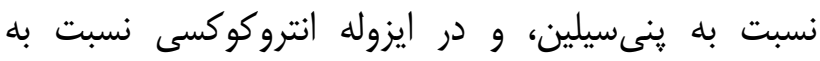

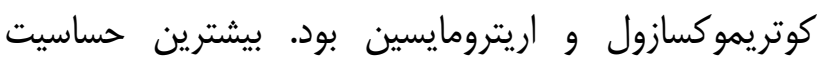

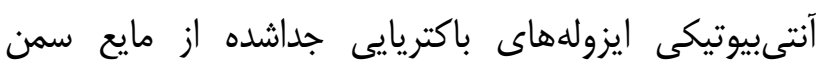

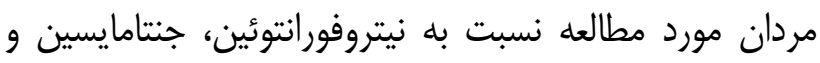

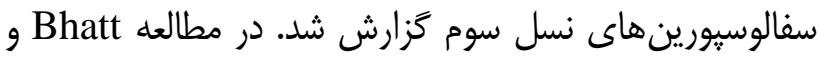

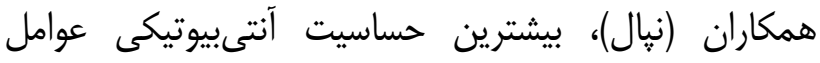
باكتريايى جداشده از مايع سمن نسبت به به نيتروفورانتوئين،

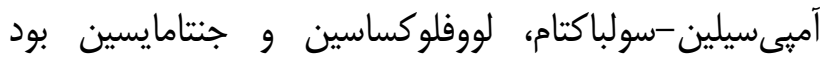

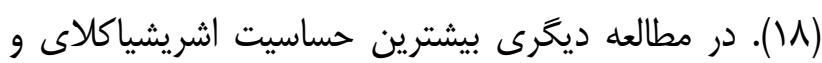

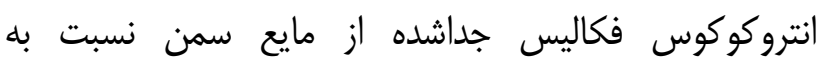
آمبىسيلين، كوتريموكسازول، نيتروفورانتوئين و اريترومايسين إنسين

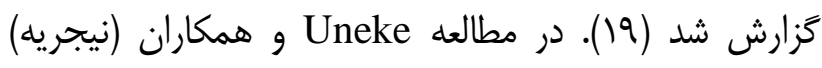

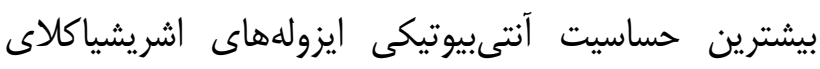

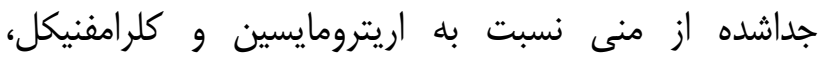

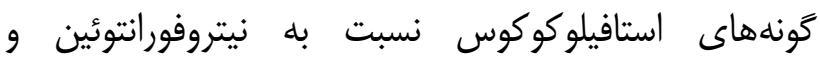

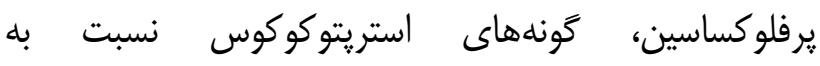
كوتريموكسازول و تتراسايكلين بود (•(1). سابقه عفونتهاى

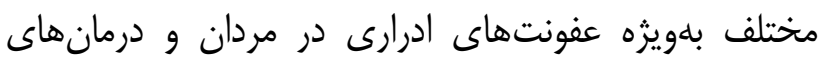

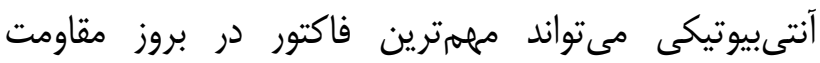
آنتى بيوتيكى در باكترىهاى آلودهكنتده مايع سمن مردان باشد.

باز جانله محدوديتهاى مطالعه حاضر، عدم بررسى

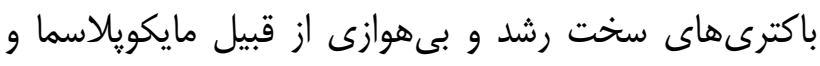

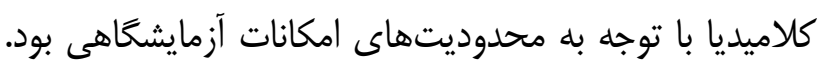

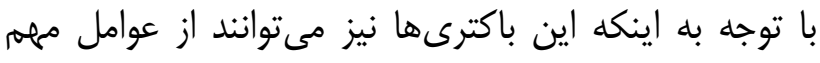

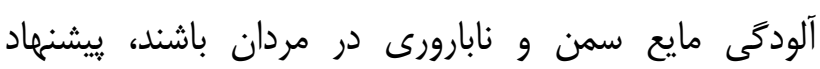

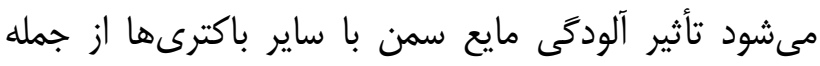

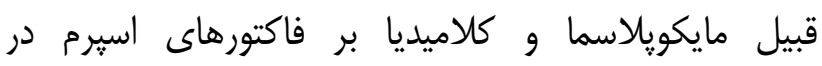
مطالعات آينده مورد بررسى قرار كيرد.

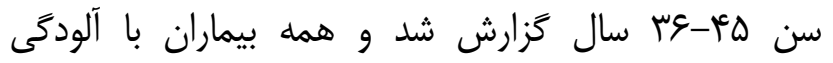

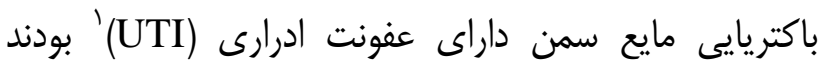

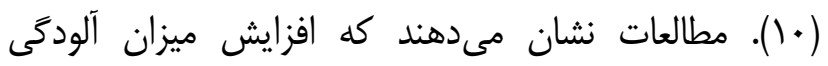

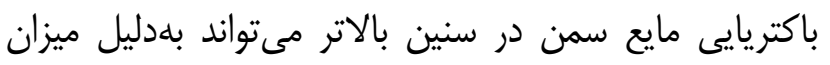

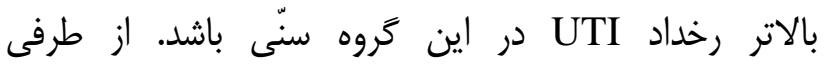

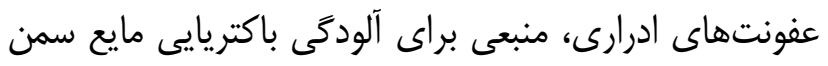

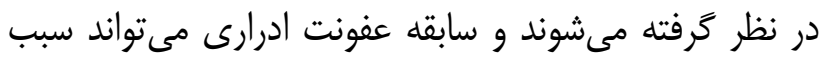

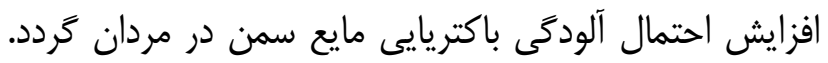

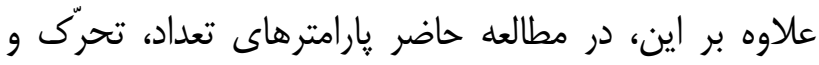

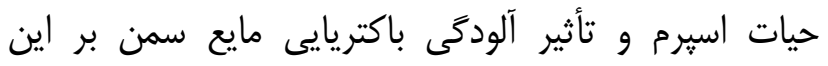

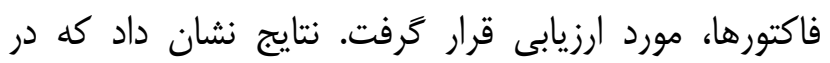

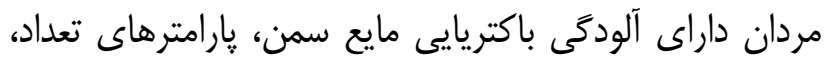

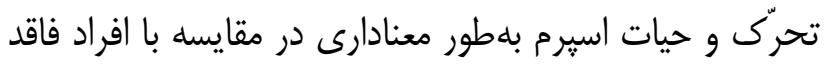

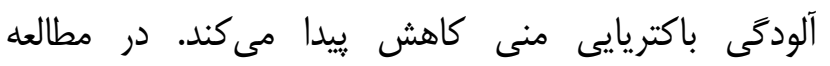
Ahmadi

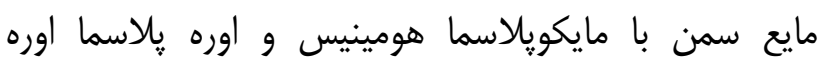

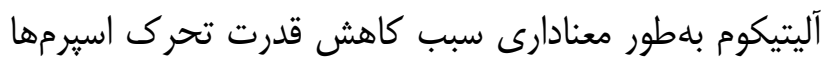
مىشود (IV). نتايج مطالعه Moretti و همكاران (ايتاليا)

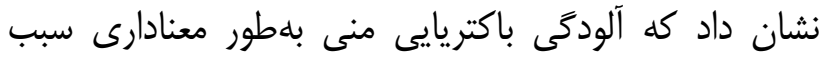

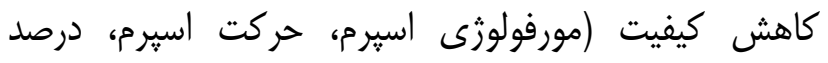
نكروزيس و آيويتوزيس) مايع سمن مىشود (9) (9). مطالعات

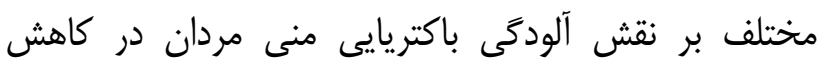

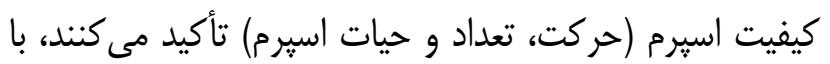

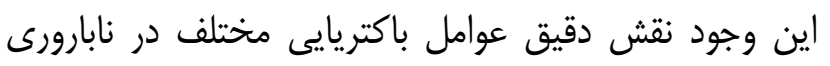
بلهور شفاف مشخص نيست و نياز به مطالعات بيشتر در اين دين

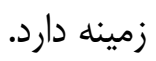
قابل ذكر است كه اجتناب از آلودگى مايع سمن تقريباً

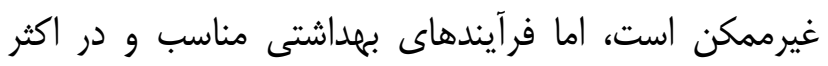

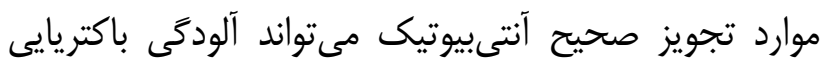
مايع سمن را بهميزان قابلتوجهى كاهش دهد (ه) (ه). در مطالعه

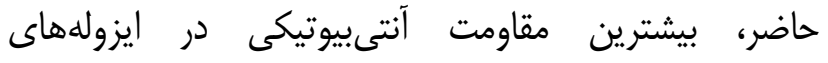




$$
\begin{aligned}
& \text { تقدير و تشكر } \\
& \text { بدينوسيله از معاونت تحقيقات و فناورى دانشگاه علوم } \\
& \text { آلودخى باكتريايى مايع سمن مى تواند سبب كاهش قابل } \\
& \text { عزشكى بيرجند، تشكر و قدردانى مى گردد. } \\
& \text { توجه حركت، حيات و تعداد اسيرم شود. با توجه بـ شئ شيوع مايع }
\end{aligned}
$$

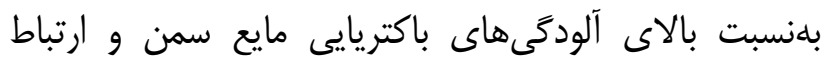

$$
\begin{aligned}
& \text { تضاد منافع }
\end{aligned}
$$

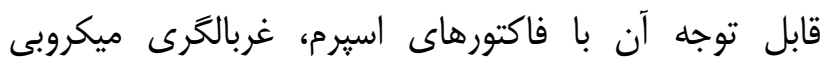

$$
\begin{aligned}
& \text { نويسندكان مقاله اعلام مى دارند هيج گَونه تضاد منافعى در } \\
& \text { زوجهاى نابارور بدون علائم بالينى ضرورى بـ نظر مى بـرسد. } \\
& \text { يزوهش حاضر وجود ندارد. }
\end{aligned}
$$

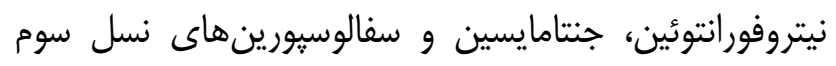

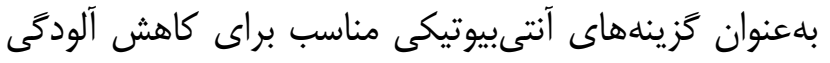

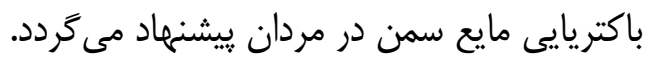

$$
\begin{aligned}
& \text { منابع: }
\end{aligned}
$$

1- Ahmad MK, Mahdi AA, Shukla KK, Islam N, Jaiswar SP, Ahmad S. Effect of Mucuna pruriens on semen profile and biochemical parameters in seminal plasma of infertile men. Fertil Steril. 2008; 90(3): 627-35. doi: 10.1016/j.fertnstert.2007.07.1314

2- Javaregowda SK, Govindagowda P, Krishna CT, Varadaraju S. A community based study to determine the prevalence of infertility and associated socio demographic factors in rural area of Mandya district of Karnataka. Int J Community Med Public Health. 2019; 6(6): 2444-8. doi: 10.18203/2394-6040.ijcmph20192302

3- Ikechebelu J, Adinma J, Orie E, Ikegwuonu S. High prevalence of male infertility in southeastern Nigeria. Journal of Obstetrics and Gynaecology. 2003; 23(6): 657-9. doi: 10.1080/01443610310001604475

4- Xu DX, Shen HM, Zhu QX, Chua L, Wang QN, Chia SE, et al. The associations among semen quality, oxidative DNA damage in human spermatozoa and concentrations of cadmium, lead and selenium in seminal plasma. Mutat Res Genet Toxicol Environ Mutagen. 2003; 534(1-2): 155-63.

5- Bennemann PE, Machado SA, Girardini LK, Sonálio K, Tonin AA. Bacterial Contaminants and Antimicrobial Susceptibility Profile of Boar Semen in Southern Brazil Studs. Revista MVZ Córdoba. 2018; 23(2): 6637-48. doi: 10.21897/rmvz.1338

6- Morrell JM. Antimicrobials in Boar Semen Extenders-A Risk/Benefit Analysis. J Antimicrob Agents. 2016; 2(1): 2472-1212. doi: 10.4172/2472-1212.1000107

7- Althouse GC. Sanitary procedures for the production of extended semen. Reprod Domest Anim. 2008; 43 Suppl 2: 374-8. doi: 10.1111/j.1439-0531.2008.01187.x.

8- Virecoulon F, Wallet F, Fruchart-Flamenbaum A, Rigot JM, Peers MC, Mitchell V, et al. Bacterial flora of the low male genital tract in patients consulting for infertility. Andrologia. 2005; 37(5): 160-5. DOI: 10.1111/j.14390272.2005.00673.x

9- Moretti E, Capitani S, Figura N, Pammolli A, Federico MG, Giannerini V, et al. The presence of bacteria species in semen and sperm quality. J Assist Reprod Genet. 2009; 26(1): 47-56. doi: 10.1007/s10815-008-9283-5.

10- Uneke CJ, Ugwuoru CD. Antibiotic susceptibility of urogenital microbial profile of infertile men in South-eastern Nigeria. Andrologia. 2010; 42(4): 268-73. doi: 10.1111/j.1439-0272.2009.00988.x.

11- CLSI. Performance Standards for Antimicrobial Susceptibility Testing. 26th ed. CLSI supplement M100S. Wayne, PA: Clinical and Laboratory Standards Institute; 2016.

12- Alavi M, Tabatabaei S, Fazaeli H, Kolhar N, Sheikh Hasan M, Ghiyasi M. Prevalence of bacterial contamination in semen samples of infertile men in Qom province. Scientific Research Applied Biology. 2016; 5(20): 28-35. [Persian] 
13- Nabi A, Khalili MA, Halvaei I. An investigation of bacterial infection of seminal fluid in men with infertility with unknown etiology. Qom Univ Med Sci J. 2014; 8(5): 48-53. [Persian]

14- Domes T, Lo KC, Grober ED, Mullen JB, Mazzulli T, Jarvi K. The incidence and effect of bacteriospermia and elevated seminal leukocytes on semen parameters. Fertil Steril. 2012; 97(5): 1050-5. doi: 10.1016/j.fertnstert.2012.01.124.

15- Merino G, Carranza-Lira S, Murrieta S, Rodriguez L, Cuevas E, Moran C. Bacterial infection and semen characteristics in infertile men. Arch Androl. 1995; 35(1): 43-7. DOI: 10.3109/01485019508987852

16- Al-Marzoqi AH, Mohammad Aboud M, Mohammad Sabri A. Study of Bacterial infection associated with male infertility in Hillah city-Iraq. J Biol Agric Healthc. 2012; 2(9): 10-6.

17- Ahmadi MH, Amirmozafari N, Kazemi B, Gilani MAS, Jazi FM. Use of PCR to detect Mycoplasma hominis and Ureaplasma urealyticum from semen samples of infertile men who referred to Royan Institute in 2009. Yakhteh. 2010; 12(3): 371-80. [Persian]

18- Bhatt C, Mishra S, Bhatt A, Lakhey M. Bacterial pathogens in semen culture and their antibiotic susceptibility pattern in vitro. Int J Biomed Res. 2015; 6(11): 909-14. doi: 10.7439/ijbr.v6i11.2694

19- Mogra N, Dhruva AK, Kothari LK. Non-specific seminal tract infection and male infertility: a bacteriological study. J Postgrad Med. 1981; 27(2): 99-104. 